\title{
METODE TAHFIDZ ALQURAN : SEBUAH PENGANTAR
}

\section{Tamrin Talebe, Isramin}

Institut Agama Islam Negeri (IAIN) Palu

\section{Abstract:}

Tahfidz Alquran or memorization of the Koran is the oldest tradition in efforts to preserve the Koran. Along with the history of Islam development, various efforts were made to preserve the tradition. The goal of become a hafidz is to achieve the salvation of his religion through the preservation of the scriptures. Various methods applied as an effort to memorize the Koran. Various methods to memorize Koran including Talqin method and Tikrar method, listening to recordings, movements and gesture methods, method of reading verses to be memorized, memorization method by recording the voice of teachers and children, method of listening to recordings of reading verses of the Qur'an from the teacher and their peers, the Sima'i / Tasmi method, the Muraja'ah method, the Jama' method or the Kitabah method.

Tahfidz Alquran atau penghafalan Alquran adalah tradisi tertua dalam upaya pemeliharaan Alquran. Seiring dengan perjalanan sejarah perkembangan Islam, berbagai upaya dilakukan untuk menanamkan tradisi tersebut. Tujuan yang ingin dicapai oleh seorang hafidz adalah mewujudkan derajat kemuliaan diri seseorang terhadap agamanya melalui pemeliharaan kitab suci. Berbagai cara diterapkan seseorang dalam upaya menghafalkan Alquran. Beberapa metode yang digunakan antara lain metode Talqin dan metode Tikrar (membaca secara istiqamah), mendengarkan rekaman, metode gerakan dan isyarat, metode membaca ayat yang akan dihafal, metode menghafal dengan merekam suara guru dan anak, metode memperdengarkan rekaman bacaan ayat Alquran dari guru dan anak sebayanya, metode Wahdah, metode Sima'i/Tasmi', metode Muraja'ah, metode Jama' atau metode Kitabah.

\section{Keyword: Metode, tahfidz, Iqra, Simai}


114 |Rausyan Fikr, Vol. 15 No. 1 Juni 2019: 113-129

\section{PENDAHULUAN}

Alquran merupakan kalam Allah swt yang memiliki sisi keunikan dalam proses menghafalnya. Setiap individu diberikan kemampuan berupa cara tertentu dalam menghafal. Waktu luang dan memanfaatkannya untuk aktifitas menghafal menjadi bagian terpenting dalam mewujudkan cita mulia tersebut. Aktifitas tahfidz Alquran ini telah menjadi bagian dari kehidupan dan menjadi tradisi utama dari generasi awal dimana Alquran diturunkan di masa Rasululah. Di antara sahabat Rasululah yang secara rutinitas melakukan tahfidz Alquran diantaranya adalah Ali bin Abi Thalib, Abu Musa al-'Asy'ari, Abdullah bin Mas'ud, Abu Darda, Zaid bin Tsabit, Utsman bin 'Affan, Umar Ibn Khattab dan sejumlah sahabat lainnya.

Sejarah perkembangan Alquran telah mencatat bahwa Rasululah bersama sahabatnya sering melakukan proses transformasi Alquran. Transformasi ini berkaitan dengan kebutuhan sahabat untuk mendapatkan ajaran ilahiyah maupun kepada Rasululah dengan kepentingan tahsin Alquran dari para sahabat. Kehidupan dengan nuansa Alquran tersebut terkadang melahirkan kesan buruk di mata musuh Islam dan berdampak negatif dengan jatuhnya korban dari para huffadz (penghafal Alquran) seperti ketika sekelompok huffadz dibantai tatkala berada di Bi'r Ma'unah.

Cara Rasululah dalam menyampaikan ayat Alquran kepada sahabat dilakukan dengan pengucapan fasih dan dalam lahjah (dialek) Quraisy. Sahabat menghafal dan menelaah ayat Alquran tidak lebih dari 10 ayat yang dilakukan melalui proses pendalaman dan implementasi makna dalam diri sahabat. Dari sisi inilah yang kemudian berkembang skema tahfidz Alquran dengan menggunakan dasar pemahaman makna dan penguatan hafalan pada tahap selanjutnya.

Cita utama Tahfidz Alquran merupakan bukti konkrit penguatan diri sebagai bagian dari ahl Alquran. Setiap orang 
Tamrin Talebe, Isramin, Metode Tahfidz Alquran... 115

diberikan kesempatan yang sama dalam melakukan penghafalan tersebut. Selanjutnya, proses ini akan terus berkembang seiring perkembangan sosial umat Islam. Keinginan dan kemauan meluangkan sebagian waktu untuk bersama dengan Alquran , dalam wujud mentradisikan membaca atau mentadarusi Alquran dengan bacaan-bacaan yang indah, seperti membaca dengan tartil maupun dengan bacaan tilawah yang tidak melanggar kaidah ilmu tajwid.

Di era saat ini, pelaksanaan tahfidz Alquran yang diselenggarakan di berbagai lembaga pendidikan pula tergambar upaya misi mengajarkan benih tauhid dan ajaran agama sedini mungkin. Dengan demikian, di kalangan pelajar melalui proses menghafalkan Alquran adalah bagian dari bentuk penanaman nilai keagamaan yang tepat dan dibarengi dengan metode yang tepat sesuai kondisi psikologis dan tumbuh kembang mereka.

\section{PEMBAHASAN}

Tahfidz Alquran merupakan gabungan kata tahfidz dan Alquran. Tahfidz adalah kata yang menunjukkan suatu keadaan dalam jiwa yang menguatkan sesuatu yang telah dicapai dengan pemahaman. Terkadang digunakan untuk menunjukkan kuatnya hafalan dalam jiwa, lawan katanya lupa. Terkadang kata ini digunakan untuk menunjukkan penggunaan kekuatan (potensi) tersebut. ${ }^{1}$ Dalam hal ini adalah proses menjaga, memelihara dan menghafal Alquran. Dalam tatanan praktisnya dapat dipahami adalah suatu upaya membaca Alquran dengan lisan sehingga menimbulkan ingatan dalam pikiran dan meresap masuk dalam hati untuk diamalkan dalam kehidupan sehari-hari. ${ }^{2}$

Terdapat banyak ragam metode dalam menghafalkan Alquran yang diterapkan untuk memenuhi capaian tersebut, diantaranya:

${ }^{1}$ Al-Ragib al-Ashfahani, Al-Mufradat fi Garib Al-Quran, (Kairo: Dar alfikr, th), 123

${ }^{2}$ Achmad Yaman Syamsuddin, Cara Mudah Mengahafal Alquran, (Solo, Insan Kamil, 2007), 20. 


\section{Metode Talqin dan metode Tikrar}

Mengajarkan anak menghafal Alquran dengan metode ini adalah dengan cara membacakan terlebih dahulu ayat dihafal secara berulang-ulang hingga anak menguasainya. Setelah anak menguasai, maka berpindah ke ayat selanjutnya. ${ }^{3}$ Terkadang pengulangan hanya dilakukan sekali dan selanjutnya adalah memperdengarkan ayat-ayat yang dihafal melalui rekaman bacaan ayat tersebut dari qari' ternama di dunia, seperti Muhammad Ayub, al-Hushari, al-Ghamidy, dan sebagainya. Rekaman ini diputar berulang kali sehingga anak hafal di luar kepala. ${ }^{4}$ Perkembangan teknologi modern melalui rekaman menghasilkan metode lain yakni pengulangan dengan rekam suara. Metode ini menggunakan media alat perekam dan membutuhkan partisipasi orang lain.

Langkah awal adalah mempersiapkan alat perekam. Suara guru dan anak direkam dalam satu rekaman bacaan yang benar dan fasih. Selanjutnya orang tua memerintahkan anak membacanya. Mendengarkan bacaan dengan seksama dan berulang adalah kunci dari metode ini.

\section{Metode gerakan dan isyarat}

Cara menghafal Alquran dengan metode ini dipelopori oleh ayah Husein ath-Thaba'thaba'i yang berhasil menjadikan anaknya ahlul qur'an sejak usia 6 tahun. Metode ini cocok untuk anak yang mempunyai daya konsentrasi pendek dan tidak bisa diam. Metode ini menarik bagi anak yang kurang tertarik dengan lafadz-lafadz ayat yang sedang dihafal. ${ }^{5}$ Sebagai contoh penggunaan metode ini adalah ketika menghafal ayat"wa aqiimush shalata, guru melakukan takbir sebagai isyarat shalat, lalu pada lafadz "wa atuz zakata, mereka menghentakkan tangan kanan seakan mengeluarkan zakat,

\footnotetext{
${ }^{3}$ Fathin Masyhud dan Ida Husnur Rahmawati, Rahasia sukses 3 Hafidz Qur'an Cilik Mengguncang Dunia, (Jakarta: Zikrul Hakim, 2016), 229.

${ }^{4}$ Ibid, 229-230.

${ }^{5}$ Ibid, 231.
} 
Tamrin Talebe, Isramin, Metode Tahfidz Alquran... 117

dan warka'u ma'ar raki'in, mereka melakukan ruku'. Ketika menggunakan metode ini, guru harus benar-benar bisa memahami benar makna dari ayat yang dihafalkan. Di samping itu, guru juga harus kreatif dalam melakukan gerakan. Kelebihan metode ini adalah, anak tidak hanya menghafalkan ayat Alquran saja, tetapi juga maknanya. Adapun kekurangan metode ini, bagi penulis adalah bahwa gerakan dan isyarat tubuh terlalu sempit untuk menggambarkan makna ayat Alquran , apalagi jika berhadapan dengan ayat yang bersifat abstrak dan cakupannya luas.

\section{Metode Qiraah (membaca)}

Metode ini memiliki kesamaan dengan metode tikrar, yang menghendaki pengulangan terus menerus. Tetapi metode qiraah ini mensyaratkan bahwa anak sudah bisa baca Alquran dengan baik. Dengan kata lain, anak menghafal sendiri dengan membaca ayat Alquran yang dihafal secara berulang-ulang, kemudian baru menghafalkannya. Metode ini diterapkan oleh santri-santri alUtrujah Jakarta yang bisa menyelesaikan hafalan 10 juz dalam waktu 10 bulan. Dengan demikian, satu bulan mereka berhasil menghafal 1 juz. ${ }^{6}$

Dalam penerapan metode qiraah, konsistensi seorang hafidz sangat diharapkan. Disiplin dalam menetapkan target hafalan adalah suatu keharusan. Target hafalan didasarkan pada pembagian surah dalam Alquran kedalam 7 (tujuh) pembagian. Proses penyetoran hafalan diharapkan memiliki konsistensi dan target baris perhari. ${ }^{7}$

Metode yang hampir serupa adalah metode wahdah. Metode ini dilakukan dengan cara menghafal satu persatu ayat-ayat yang akan dihafal, bukan berdasarkan baris seperti metode utrujah. Materi ayat selanjutnya akan ditambahkan ketika telah lancar. Metode ini sangat mengedepankan kemudahan tanpa jumlah ayat

\footnotetext{
${ }^{6}$ Ibid.

${ }^{7}$ Ma'had al-Utrujah li Tahfidz Alquran, Metode Menghafal Alquran Secara Cepat dan Sederhana.
} 
yang lebih. Ayat yang dibaca dengan cara mengulang sebanyak 15 kali, atau 20 kali atau 25 kali atau bahkan lebih. ${ }^{8}$

\section{Metode dengar anak sebayanya}

Metode ini memiliki kemiripan dari metode sebelumnya. Sisi perbedaan terletak pada pengaruh sumber suara. Setiap individu memiliki perbedaan kemampuan hafalan berdasarkan sumber suara yang disenangi. Suara teman, suara orang yang lebih tua ataupun suara dari seorang yang populer. Komponen yang harus diwujudkan adalah tersedianya suara hasil rekaman sebagai hal pokok, tehnik meniru dari sekelompok anak yang bersuara dan bacaan yang baik, meniru beberapa kali dengan bersama-sama, mengulang-ulang hasil rekaman di rumah dan diterapkan dalam kondisi yang menyenangkan. Dengan demikiann, anak-anak dengan sendirinya akan menghafalkan bacaan tersebut, bahkan mereka akan mengulang-ulangi ketika mereka bertemu teman-temannya. Metode ini diterapkan berdasarkan asumsi bahwa anak suka meniru anak sebayanya, sehingga ketika mereka mendengar suara anak sebayanya, mereka cenderung ingin menirunya. Metode ini cocok untuk ibu-ibu rumah tangga yang sering melakukan banyak pekerjaan rumah.

\section{Metode Sima'i/Tasmi'}

Metode sima'i adalah metode menghafal Alquran dengan cara mendengar. Metode ini dilakukan dengan mendegar ayat-ayat al- Qur'an yang akan dihafal baik dari seseorang hafidz maupun mendengar melalui media elektronik seperti handphone, laptop, netbook, dan sejenis lainnya. Senada dengan yang dikatakan oleh Dr. Kamil al- Labudy, ayah dari tiga hafidz cilik; Tabarak, Yazid, dan Zaina, menceritakan bahwasanya kebiasaan yang sering ia lakukan di rumah adalah memutar kaset murattal Alquran . Anakanaknya ia biarkan bermain, sebab itu masih usia bermain mereka.

${ }^{8}$ Umar al-Faruq, 10 Jurus Dahsyat Menghafal al-Qur'an (Surakarta: Ziyad, 2014), 86-90. 
Sambil bermain mereka terus mendengarkan murattal. Lama-lama akhirnya mereka hafal ayat-ayat tersebut. ${ }^{9}$

Metode sima' $i$ sangat efektif bagi orang-orang belumbisa membaca Alquran, tunanetra, maupun individu yang sibuk dengan pekerjaanya sehingga tidak sempat membaca Alquran . Selain itu jika telinga sudah terbiasa serasi dan peka terhadap bahasa atau ucapan yang didengar maka mudah mengerti. ${ }^{10}$ Artinya ketika seorang anak atau mahasiswa sering mendengarkan bacaan-bacaan Alquran maka akan terasa mudah dalam menghafalkan Alquran karena sudah terjalin kuat antara pendengaran dengan ayat-ayat Alquran yang kemudian menimbulkan motivasi ingin menjadi hafidzullah yang alim yang mampu mengamalkan pesan-pesan moral dalam ayat-ayat Allah swt.

\section{Metode Muraja'ah}

Metode menghafal muraja'ah adalah metode menghafal Alquran dengan cara mengulang kembali hafalan yang pernah dihafal dengan tujuan agar hafalan tetap terjaga. Mengulang hafalan dapat dilakukan dengan cara meminta bantuan teman sejawat, mengulang ketika waktu salat atau muraja'ah dengan kepada guru ngaji. ${ }^{11}$

Sedangkan menurut Abdul Aziz bahwa sebelum mulai menghafal, maka bacalah berulang-ulang ayat yang akan dihafal sebanyak 35 kali pengulangan. Karena dengan cara ini akan merasakan kemudahan khusus dalam merekam ayat-ayat tersebut. Namun cara ini membutuhkan waktu yang cukup banyak. ${ }^{12}$ Senada dengan yang dikatakan oleh Abu Hurri beliau mengatakan bahwa kuatnya seseorang atau lembaga dalam bidang tahfidz adalah muraja'ah. Abu Hurri juga membagi tiga macam metode

${ }^{9}$ Ibid, 107.

${ }^{10}$ Tayar Yusuf dan Syaiful Anwar, Metodologi Agama dan Bahasa Arab (Jakarta: PT. RajaGrafindo Persada, 1997), 178.

${ }^{11}$ Umar al-Faruq, 10 Jurus Dahsyat... 135.

${ }^{12}$ Abdul Azis Abdul Rauf Al Hafizh, Kiat Sukses Menjadi Hafizh Qur'an Da'iyah, 51. 
muraja'ah yang efektif dalam menghafal Alquran yaitu: muraja'ah dengan diri pribadi, muraja'ah dengan teman, dan muraja'ah dengan guru (pengajar). ${ }^{13}$

\section{Metode Jama'}

Metode Jama' adalah metode menghafal Alquran dengan cara bersama-sama yang dipimpin oleh ketua atau instruktur dalam kelompok. Dengan cara instruktur membaca satu ayat atau dua ayat atau tiga ayat atau lebih kemudian ditiru oleh anggotanya atau pesertanya. Setelah ayat-ayat yang dibimbing oleh instruktur tersebut dibaca dengan baik, maka peserta diminta untuk perlahan melepas mushaf kemudian menghafal secara perlahan-lahan.

Dengan metode menghafal secara jama' seperti ini setidaknya dapat membantu peserta untuk semangat dalam menghafal. Karena dengan komunitas, teman dan secara bejama'ah tentunya akan lebih mendorong diri untuk lebih bersemangat. ${ }^{14}$

\section{Metode Kitabah}

Metode kitabah adalah metode menghafal Alquran dengan cara menulis ayat- ayat Alquran pada potongan kertas atau dalam catatan-catatan tertentu yang akan mempermudah hafalan. Selain itu cara ini sebenarnya sudah sering dilakukan para ulama zaman dahulu, setiap ilmu yang mereka hafal mereka tulis. Hal ini dapat kita lihat dalam gubahan sya'ir mereka yang menganjurkan penulisan ilmu. ${ }^{15}$

Dari beberapa metode-metode tahfidz Alquran di atas penulis memberikan penjelasan sedikit bahwa mode-metode tersebut cocok kepada anak-anak usia dini, anak remaja, orang dewasa bahkan bisa diterapkan ke umum, karena sebenarnya kunci utama menghafal Alquran bukan terletak pada metode-metode tahfidznya saja tetapi terletak pada diri orang yang ingin menjadi

${ }^{13}$ Abu Hurri, Cepat dan Kuat Hafal Juz'amma (Sukoharjo:Al-Hurri Media Qur'anuna, 2010), 52-53.

${ }_{14}^{14}$ Umar al-Faruq, 10 Jurus Dahsyat... 97.

${ }^{15}$ Abdul Azis Abdul Rauf Al Hafizh, Kiat Sukses ..., 53. 
Tamrin Talebe, Isramin, Metode Tahfidz Alquran... 121

seorang hafidz, seperti seberapah besar cintanya terhadap Alquran , seberapah banyak ia membaca Alquran dalam setiap harinya dan sekuat apa sifat istiqamahnya bersama kalam Allah yang mulia tersebut. Inilah sebahagian sifat yang dapat mengantarkan seorang manusia menjadi nyata hafidz Alquran bukan menjadi hafidz hayalan atau hafidz imajinasi. Hayalan tersebut bisa berubah menjadi kenyataan apabila dibarengi dengan usaha yang sungguhsungguh bukan usaha main-main.

\section{FAKTOR PENUNJANG KEBERHASILAN TAHFIZ ALQURAN}

Dalam setiap proses, apapun itu, pastilah ada faktor atau unsur yang menjadikan proses itu menuai hasil yang diinginkan. Begitu pula dengan proses menghafalkan Alquran , apalagi untuk anak usia dini, yang tentu saja membutuhkan pertimbangan khusus, demi mencapai keberhasilan. Faktor kesadaran dan tujuan dari program hafalan Alquran harus didasarkan pada cita-cita luhur. Diantara faktor penunjang keberhasilan tersebut adalah :

1. Menyadari fitrah

Manusia memiliki fitrah dan kecenderungan kemampuan dalam mengola potensi dirinya. Seorang anak memiliki kecenderungan untuk bermain dan metode yang dibutuhkan dalam proses tahfidz Alquran harus mengikuti irama perkembangannya. Ini dilakukan untuk memenuhi unsur dalam perkembangan kognitif diri seorang anak. Pelaksanaan program haruslah bertujuan membantu tumbuh kembang anak, menyenangkan dan dapat merehatkan pikiran dari kejenuhan belajar. Sebuah program harus didasarkan pada memaksimalkan potensi gerak motorik dan gerak aktif seorang anak. Tidak mengganggu orang lain serta tidak membahayakan diri mereka dan orang lain. ${ }^{16}$ Hal lain sebagai

\footnotetext{
${ }^{16}$ Fathin Masyhud dan Ida Husnur Rahmawati, Rahasia sukses..., 167-
} 168. 
bentuk fitrah anak adalah adanya ransangan materi dan moril atas setiap prestasi hafalan yang diraih seorang anak.

2. Peran orang tua

Peran orang tua sangat memiliki arti penting mendorong anak dalam menghafalkan Alquran. Fitrah yang ada dalam diri seorang anak harus diketahui oleh setiap orang tua atau pelaksana program tahfidz Alquran. Memahami potensi harus dibarengi dengan wujud dari komitmen tersebut. Orang tua berperan membangkitkan semangat, mengawasi dan mendampingi anak dalam proses menghafalkan Alquran , serta menjaga ke-istiqomahan rutinitas terkait proses menghafal. ${ }^{17}$

3. Manajemen waktu

Manajeman waktu yang dimaksudkan adalah kemampuan memilih waktu yang tepat dalam melakukan hafalan. Mengelola waktu sangat terkait dengan kemampuan melakukan proses menghafal, baik terhadap upaya penambahan atau pun dalam pengulangan. Di samping tetap mempertimbangkan kebutuhan dasar seorang anak, seperti bermain. Ketika anak lebih banyak mengulang hafalan tanpa menambahnya, maka anak akan mengalami kejenuhan. Begitu pula ketika anak hanya dituntut untuk menghafal atau belajar saja tanpa menyisihkan waktu untuk bermain, tentu akan mempengaruhi tumbuh kembang motorik dan sosial anak tersebut.

4. Istiqomah/kesinambungan

Program hafalan Alquran sangat membutuhkan keseriusan. Faktor ini sangat menentukan efektifitas program. Target yang diinginkan harus didukung komitmen waktu. Setip orang memiliki potensi dan kesempatan yang sama dalam mewujudkan program yang dijalankan. Hasil yang dicapai akan beragam karena kemampuan mengolah dan melakukannya dengan penuh komitmen. Proses menghafal Alquran harus memenuhi unsur dalam kebutuhan

\footnotetext{
${ }^{17}$ Ibid, 190.
} 
Tamrin Talebe, Isramin, Metode Tahfidz Alquran... 123

dirinya. Kejiwaan tidak terbebani karena program tahfidz Alquran dan program ini pun harus dapat diselenggarakan dengan sebaikbaiknya.

5. Faktor kesehatan

Kesehatan merupakan salah satu faktor yang sangat penting bagi orang yang akan menghafalkan Alquran . Jika kondisi tubuh selalu sehat maka proses menghafalkan menjadi lebih mudah dan dapat memenuhi target yang diinginkan. Sebaliknya, bila tubuh terganggu, maka proses mengahafal Alquran akan mengalami gangguan. Konsentrasi akan tidak vokus dan target yang diinginkan tidak dapat dicapai secara sempurna. Menjaga kebugaran tubuh, menjaga pola makan, waktu istirahat yang teratur menjadi faktor pendukung dalam program ini.

6. Faktor Psikologis

Kesehatan yang diperlukan oleh orang yang menghafalkan Alquran tidak hanya dari segi kesehatan lahiriah, tetapi juga dari segi psikologisnya. Jiwa yang baik pada diri seseorang akan semakin mamacu semangat. Menghafal Alquran membutuhkan ketenangan jiwa, baik dari segi pikiran maupun hati. Kejiwaan dalam program tahfidz Alquran sangat dibutuhkan, beban emosional yang tenang akan mempengaruhi tingkat konsentrasi diri. Dalam situasi seperti ini seorang penghafal harus mampu menenangkan dirinya dalam mengingat prinsip menghafalkan Alquran.

7. Faktor Kecerdasan

Kecerdasan merupakan salah satu faktor pendukung dalam menjalani proses menghafalkan Alquran . Setiap individu mempunyai kecerdasan yang berbeda-beda. Sehingga, cukup mempengaruhi terhadap proses hafalan yang di jalani. Meskipun demikian, bukan berarti kurangnya kecerdasan menjadi alasan untuk tidak bersemangat dalam proses menghafalkan Alquran . Menghafal Alquran membutuhkan kemampuan mengingat yang harus terus diasah. Bahwa manusia memiliki potensi yang sama, 
maka hal terpenting adalah memaksimalkan kecerdasan tersebut terhadap suatu program.

8. Faktor Motivasi

Orang yang menghafalkan Alquran, pasti membutuhkan motivasi dari orang-orang terdekat, kedua orang tua, keluarga, dan anak kerabat. Dengan adanya motivasi, ia akan lebih bersemangat dalam menghafal Alquran . Tentunya, hasilnya akan berbeda jika motivasi yang didapatkan kurang. Kurangnya motivasi dari orangorang terdekat atau dari keluarga menjadi salah satu faktor penghambat bagi sang penghafal itu sendiri. ${ }^{18}$

\section{Faktor Usia}

Usia bisa menjadi salah satu faktor penghambat bagi orang yang hendak menghafalkan Alquran . Jika usia penghafal sudah memasuki masa-masa dewasa, maka akan mengalami kesulitan dan menjadi penghambat. Selain itu, kemampuan otak orang dewasa dalam melakukan proses mengingat juga tidak semudah yang lebih muda. Menghafal Alquran bagi orang dewasa membutuhkan tehnik tersendiri, meskipun demikian tidak secepat daya tangkap seperti usia muda. Akan tetapi, di usia dewasa akan banyak hal yang masih harus dipikirkan, selain menghafal Alquran . Usia muda adalah usia yang tepat untuk melaksanakan program tahfidz Alquran.

Walaupun menghafal Alquran bukan sesuatu yang sangat susah, namun membutuhkan kesabaran ekstra. Pada dasarnya, menghafal Alquran tidak hanya sekadar menghafal, melainkan juga harus menjaganya dan melewati berbagai rintangan atau cobaan selama menghafal. Jika ingin mencapai sebuah kemulian maka harus melewati banyak ujian dan cobaan. Untuk itu penghafal harus melaluinya dengan penuh istiqamah dan ketabahan, apabila seorang calon hafidz tidak menjalaninya dengan sungguh-sungguh maka akan gagal menjadi sorang hafidz karena tidak bisa mencapai target yang telah dicita-citakan dan didambakan. sifat yang perlu

\footnotetext{
${ }^{18}$ Wiwi Alawiyah Wahid, Cara Cepat ..., 141.
} 
Tamrin Talebe, Isramin, Metode Tahfidz Alquran... | 125

diperlukan dalam menghafal Alquran adalah kesabaran tanpa adanya sebuah kesabaran, maka tidak akan mungkin mencapai titik akhir yang sempurna sesuai dengan yang dicita-citakan. Mengeluh bukanlah sebuah solusi yang baik ketika sedang menjalani proses menghafal Alquran . Apabila sering mengeluh dalam menghadapi ujian dan cobaan yang belum bisa diselesaikan, hal tersebut akan menghambat kesuksesan diri sendiri dengan pemikiran yang tidak positif dan tidak menerima segala sesuatu dengan ikhlas dan ketulusan hati.

Menjaga hafalan Alquran tidak semudah ketika menghafal Alquran . Bisa jadi dalam proses menghafal, seorang hafidz pernah merasakan cepat menghafal ayat Alquran, namun juga cepat hilangnya. Hal demikian sangat wajar dan pernah dirasakan oleh orang-orang yang menghafalkan Alquran . Oleh karena itu, menjaga hafalan yang harus benar-benar dijaga supaya tidak cepat hilang. ${ }^{19}$ Banyak sekali faktor yang menjadikan penyebab cepat hilangnya hafalan Alquran. Salah satu hal yang harus dihindari apabila benarbenar ingin menjadi penghafal Alquran, harus menjauh dari maksiat. Inilah salah satu kunci utama agar bisa menjaga hafalan Alquran . Meskipun demikian, bukan berarti hanya menjauhi maksiat yang menjadi prioritas utama, ada beberapa hal lain yang juga harus diperhatikan. Secara umum ada beberapa faktor yang dapat menghilangkan hafalan Alquran di antaranya:

1. Hati dan Pikiran

Sebagai penghafal Alquran atau siapa saja wajib menjauhi perbuatan-perbuatan yang berbau maksiat, karena gemar melakukan kemaksiatan hafalan Alquran nya pun hilang bahkan lantaran sering berbuat pelanggaran-pelanggaran syariat Allah mengakibatkan hati menjadi gelap, keruh, lupa dan terlena. Biasanya kemaksiatan terjadi berawal dari pendengaran melalui telinga, mata, lisan, tangan, dan hati. Ini yang kemudian menjadikan hati kehilangan

${ }^{19}$ Wiwi Alawiyah Wahid, Cara Cepat., 126. 
eksistensi sifat kesuciaanya, fungsi hati menjadi gelap, kotor, cahaya imannya tercabut, sampai-sampai cahaya Alquran tidak bisa lagi dirasakan disebabkan oleh banyaknya noda-noda dosa. ${ }^{20}$

\section{Moral}

Seorang penghafal Alquran hendaknya selalu menjaga moral, terutama dari sifat yang sombong. Mengabaikan moral akan menyebabkan hafalan Alquran mudah lupa dan terbengkalai. Moral adalah proses penataan yang ideal berlaku secara universal dan abstrak. Posisi seorang hafidz sangat ditentukan diterima tidaknya dalam suatu masyarakat. Situasi ini pula yang menyebabkan seorang yang melakukan program tahfidz dapat memenuhi target yang diinginkan. ${ }^{21}$

\section{Konsistensi}

Hafalan akan cepat atau mudah hilang jika tidak konsisten dalam mentakrir hafalan Alquran . Misalnya, mentakrir-nya hanya sesekali waktu, hal semacam itu sangat mempengaruhi hafalan seorang hafidz bahkan Alquran yang sudah susah payah berhasil dihafal akan hilang dan terlupakan begitu saja. Selain itu seorang hafidz juga harus disiplin agar hafalan tidak mudah hilang. Jika seorang calon hafidz kesulitan membagi waktu karena banyaknya kesibukan, maka susunlah semua kegiatan atau jadwal sehari-hari dengan baik. Sediakanlah ruang dan kesempatan untuk men-takrir hafalan, sesibuk apa pun, seorang hafidz pasti tahu waktu yang tepat dan bisa untuk men-takrir hafalan.

\section{Pengulangan (repetition)}

Seorang penghafal Alquran harus memiliki jadwal khusus untuk mengulang hafalan. Pengulangan bacaan Alquran dapat dilakukan dalam aktifitas yang memungkinkan bacaan Alquran

\footnotetext{
${ }^{20}$ How To Memorize The Qur'an, http://wikihow.com.

${ }^{21}$ Lihat Jurnal https://www.jurnal.id
} 
terulang kembali. Aktifititas yang dimaksudkan adalah bacaan Alquran dilafalkan dalam shalat atau di luar shalat. ${ }^{22}$

\section{Melakukan Proses Simak}

Salah satu metode agar hafalan tidak mudah lupa adalah dengan melakukan proses menyimak dengan sesama teman, senior, atau kepada guru dari ayat-ayat yang telah di hafal. Namun jika seorang hafidz malas atau tidak mengikuti proses ini, maka hal tersebut akan menyebabkan hafalan mudah hilang. Tahapan simak ini juga sangat memungkinkan mengurangi tingkat kesalahan dalam bacaan, karena mendapatkan monitor dari teman lainnya. ${ }^{23}$

6. Tergesa-gesa

Tergesa-gesa atau terburu-buru adalah salah satu kebiasaan yang harus dihindari dari diri seorang penghafal. ${ }^{24}$ Keinginan untuk menambah materi dapat dilakukan jika hafalan sudah kokoh/ dhabit. Jika hal ini tidak diindahkan dalam waktu yang singkat, padahal hafalan yang lama masih belum kokoh. Jika hafalan belum dhabit dan lancar, jangan sekali-kali berpindah ke hafalan yang baru. Sebab apabila hafalan sebelumnya belum dhabit, usaha hafalan yang sudah dilakukan akan menjadi sia-sia saja. Oleh karena itu, supaya hafalan tidak mudah hilang buatlah target hafalan dalam setiap harinya,dan teruslah mengulang-ualng hafalan sampai kuat dan lancar. ${ }^{25}$

\section{KESIMPULAN}

Menghafal Alquran merupakan suatu proses, mengingat materi yang dihafalkan harus sempurna, karena ilmu tersebut

${ }^{22}$ Wiwi Alawiyah Wahid, Cara Cepat ..., 135.

${ }^{23}$ Di sadur dari Yahya Abdul Fattah Az-Zawawi, Khairu Mu'in fi Hifdzi al-Qur'an al-Karim diterjemahkan oleh Dinta dengan judul; Revolusi Menghafal al-Qur'an Cepat Menghafal, Kuat Hafalan dan Terjaga Seumur Hidup (Cet. Ke8; Solo: Insan Kamil, 2015), h. 87. Lihat juga buku Abdussalam Al-Adindani, Kaifa Tahfazhul Qur'an, 57-59.

${ }^{24}$ Lihat QS. Al-Qiyamah; 16-19

${ }^{25}$ Wiwi Alawiyah Wahid, Cara Cepat..., 138. 
dipelajari untuk dihafalkan, bukan untuk sekedar dipahami. Memberikan pendidikan kepada anak di usia dini sampai usia dewasa adalah hal yang penting dan sangat ditekankan. Hal ini mengingat bahwa membiasakan anak untuk melakukan hafalan akan memberikan pengaruh intelektualitas pada masa selanjutnya. Dengan demikian, menghafalkan Alquran adalah bentuk pendidikan anak-anak yang tepat, jika ditempuh dengan metode yang tepat sesuai tumbuh kembang mereka.Terdapat banyak ragam metode menghafalkan Alquran untuk anak-anak ataupun usia remaja hingga dewasa. Dari pembahasan penelitian ini, penulis meringkas metode tersebut, yakni metode atau metode talqin, mendengarkan rekaman bacaan Alquran, baik dari CD murottal qari' terkenal, suara guru maupun suaranya sendiri dan metode gerakan dan isyarat, metode wahdah, metode jama', metode murajaah, metode sima'i atau Tasmi' dan metode kitaba. Metode ragam metode tersebut juga bisa dikombinasikan. Para orang tua atau guru hendaknya memilihkan metode yang tepat disesuaikan dengan kondisi anak dan lingkungannya. Faktor utama dalam keberhasilan dalam membimbing anak-anak dalam menghafalkan Alquran adalah niat dan doa yang ikhlas. Selain itu, beberapa hal ini tidak boleh diabaikan, yakni tidak menyalahi fitrah anak, peran orang tua yang optimal, manajemen waktu yang baik dan konsistensi serta komitmen dalam menjalankan rutinitas terkait proses menghafalkan Alquran .

\section{DAFTAR PUSTAKA}

al-Ashfahani, Al-Ragib, almufradat fi garib Alquran, Kairo: Dar alfikr, tth.

Abdul Rauf Al Hafizh, Abdul Azis, Kiat Sukses Menjadi Hafizh Qur'an Da'iyah Bandung: PT. Syaamil Cipta Media, 2004.

al-Faruq, Umar. 10 Jurus Dahsyat Menghafal Alquran Surakarta: Ziyad, 2014. 
Tamrin Talebe, Isramin, Metode Tahfidz Alquran... |

129

Hurri, Abu, Cepat dan Kuat Hafal Juz'amma Sukoharjo:Al-Hurri Media Qur'anuna, 2010.

El-Hamidy, Abdul Hakim, Kisah Bocah 3,5 Tahun dan Nenek 80 Tahun Penghafal Alquran Bandung: Puspa Swara, 2010.

Masyhud, Fathin dan Ida Husnur Rahmawati, Rahasia sukses 3 HafidzQur'an Cilik Mengguncang Dunia, Jakarta: Zikrul Hakim, 2016.

An-Najah, Ahmad Zain, Tanya Jawab Ringan dan Aktual Seputar Puasa, Cet. 4; Aqwam, 2012.

Yusuf, Tayar dan Syaiful Anwar, Metodologi Agama dan Bahasa Arab Jakarta: PT. Raja Grafindo Persada, 1997.

Wahid, Wiwi Alawiyah. Cara Cepat Bisa Menghafal Alquran Cet. 1; Jogjakarta: DIVA Press, 2012.

Az-Zawawi, Yahya Abdul Fattah, Khairu Mu'in fi Hifdzi Alquran al-Karim diterjemahkan oleh Dinta dengan judul; Revolusi Menghafal Alquran Cepat Menghafal, Kuat Hafalan dan Terjaga Seumur Hidup Cet. Ke-8; Solo: Insan Kamil, 2015. 